\title{
Status of Household's Ducks and their Associated Factors under Scavenging System in a Southern Area of Bangladesh*
}

\author{
Ghosh $\mathrm{S}^{1}$, Haider $\mathrm{N}^{2}$ and Khan $\mathrm{MKI}^{1^{*}}$ \\ ${ }^{I}$ Department of Genetics and Animal Breeding, Chittagong Veterinary and Animal Science University, Khulshi, \\ Chittagong-4225, Bangladesh, ${ }^{2}$ International Centre for Diarrheal Disease Research, Dhaka, Bangladesh
}

[Received: Oct 17, Accepted: Nov 10, 2012]

\begin{abstract}
This study was carried out to assess the status of household ducks and factors affects the productivity of ducks in Companiganj upazila under Noakhali district of Bangladesh. For this study the information was collected by direct interview using a questionnaire from 30 households. The study showed that duck rearing was mostly lead by the women $(80 \%)$ and their level of education varied from primary (43\%) to higher secondary (7\%). The average farm size was found to be six and they were mostly local ducks (90\%). Marshy lands were common (67\%) to the surroundings of the duck habitats. Most of the farmers depended on natural feed sources (60\%) while some provided supplementary feed $(40 \%)$ for their ducks. As a supplementary feed, $27 \%$ of the farmers used rice polish and $17 \%$ used a mixture of rice polish and boil rice. Duck started their first laying at 6 months of age and the mean egg production per duck per year was $114 \pm 16$ no. The diseases were more common during winter $(63 \%)$ than other seasons of the year. It was found that good egg production (> mean production) was associated with the regular use of anthelmintics, supplementary feed, presence of marshy land and regular treatment. Zending was found to be good egg producer in marshy area than other three native breeds of ducks.
\end{abstract}

Key words: Duck production, Scavenging system, performance and factors.

\section{INTRODUCTION}

Duck contributes major source of animal protein in Bangladesh and it is an important component of farming system and plays a significant role to rural economy. Duck farming creates employment opportunity for rural people, particularly for small and landless

Farmers ${ }^{[1]}$. It appears that the ducks can be raised cheaper than broiler if the market is properly organized ${ }^{[2]}$. Moreover, duck rearing is suitable for wide spread implementation as it is of low cost, requires little skills, is highly productive and can be incorporated into the household works ${ }^{[3]}$. About 95\% of the ducks reared in Bangladesh are of the indigenous type ${ }^{[4]}$. There are approximately 42.124 million duck population in Bangladesh (Bangladesh Economic Review 2012) of which most of the ducks are reared in backyard system. Duck rearing is considered to be potential both for poverty alleviation and food production, especially for the rural poor women ${ }^{[5]}$. It is an important source of cash income for the rural women. Poultry keeping is traditionally the role of women in many developing countries including Bangladesh. Female-headed households represent 20 to 30 percent of all rural households in Bangladesh ${ }^{[6]}$, and women are more disadvantaged in terms of options for income generation. Without interventions, the mortality rate of poultry was reported to be $35-85 \%$ due to diseases and predators ${ }^{[3]}$. Fluctuations in feed availability from natural sources often affect production costs which is varies from $72 \%$ to $87 \%$ of the total production costs ${ }^{[7]}$. The average egg production increased from $30 \%$ in the dry period to $62 \%$ in the scavenging period. Scavenging ducks are allowed to forage different types of faunas such as snails, fish, earthworms and flora such as duckweed and algae. Production performances of scavenging ducks without or with $65 \mathrm{~g}$ concentrate supplementation was measured ${ }^{[8]}$ and supplementation was found to improve egg production by almost four times.

Noakhali is a southern district of Bangladesh with a coastal and riverine topography. Companiganj Upazila (sub-district) under Noakhali had a historical duck rearing culture in household level (backyard). Availability of natural feed, plenty marshy land enhances the duck rearing in this area. Maijer [9] found that $60 \%$ of the households kept ducks in Noakhali region in where ducks lay about 60-90 eggs per year.

Considering the above importance, the present study was undertaken with the following objectives to (i) evaluate the status of household's ducks and their production performance and (ii) identify factors affecting productive performance of ducks.

\section{MATERIALS AND METHODS}

A survey was carried out in six different villages of Companiganj upazila under Noakhali district of Bangladesh on scavenging ducks and their raisers from July to September' 2010. A list of all the villages of this area was prepared from where six villages were randomly selected. From each village, five households were enrolled. The centre of the village was located by asking the rural people. Reaching to the centre, a household was randomly 
selected from any direction and enrolled every third households to get a total of five household from one village. In this way, a total of 30 households were chosen from all the six villages.

Table 1. Demography and husbandry practices by the duck raisers in Companigonj Upazilla under Noakhali District of Bangladesh the primary duck raisers were female $(80 \%)$ and aged between 15 and 55 with a mean of 36 years. Nearly half of the studied farmers $(43 \%)$ had primary education while one fifth $(23 \%)$ was illiterate. Agriculture (47\%) was the most common profession of the study population. On an average each study households had 6 ducks of which local duck

\begin{tabular}{|c|c|c|}
\hline SL. No. & Variables & Results \\
\hline 1. & Mean age of the primary duck raiser (in years) & $36.13 \pm 11.10($ range $15-55)$ \\
\hline \multirow[t]{3}{*}{2.} & Sex of the duck raiser & \\
\hline & Male & $6(20 \%)$ \\
\hline & Female & $24(80 \%)$ \\
\hline \multirow[t]{5}{*}{3.} & Literacy level of the duck raisers & \\
\hline & Illiterate & $7(23.3 \%)$ \\
\hline & Primary & $13(43.3 \%)$ \\
\hline & Secondary & $8(26.7 \%)$ \\
\hline & Higher secondary & $2(6.7 \%)$ \\
\hline \multirow[t]{6}{*}{4.} & Farmers occupation & \\
\hline & Agricultural & $14(46.7 \%)$ \\
\hline & Employee & $7(23.3 \%)$ \\
\hline & Farming & $2(6.7 \%)$ \\
\hline & Business & $2(6.7 \%)$ \\
\hline & Day laborer & $5(16.7 \%)$ \\
\hline \multirow[t]{5}{*}{5.} & Breeds of duck & \\
\hline & Deshi white & $4(13.3 \%)$ \\
\hline & Deshi black & $7(23.3 \%)$ \\
\hline & Deshi mix & $10(33.3 \%)$ \\
\hline & Zending & $9(30.0 \%)$ \\
\hline 6. & Average number of ducks per house holds & $6.46 \pm 1.81(4-11)$ \\
\hline 7. & Average number of laying ducks per house holds & $4.10 \pm 1.47(2-7)$ \\
\hline 8. & Presence of marshy land ( $0.5 \mathrm{~km}$ from households) & $20(66.7 \%)$ \\
\hline \multirow[t]{3}{*}{9.} & Duck and chicken rearing in a common place & \\
\hline & Yes & $11(36.7 \%)$ \\
\hline & No & $19(63.3 \%)$ \\
\hline
\end{tabular}

A questionnaire was developed which was mainly highlighted with demography of the duck farmers, feeding practice, grazing system, productive performance, vaccination and medication that is the associated factors of the duck rearing etc. The data was collected through direct interview methods. The collected data were edited and analysis with Microsoft Excel. The mean differences were compared by using least significant difference test (lsd) according to Steel et al., (1997) ${ }^{[10]}$.

\section{RESULTS AND DISCUSSION}

Demography and husbandry practices by the duck raisers

Demography and husbandry practices by the duck raisers in Companiganj upazila under Noakhali district of Bangladesh is shown in Table 1. Most of comprised $70 \%$ of the breeds available with few Zending (30\%). Marshy lands were common (67\%) to the surroundings of the duck habitats and the ducks are grazing in the marshy land (Figure 1). The studied farmers had both ducks and chicken and they reared both duck and chicken together at $64 \%$ cases. All the funds for rearing the duck belonged to the owners themselves.

\section{Farm characteristics and productive performances of duck in study area}

Ducks were raised depending on both natural and additional feed. Farm characteristics and productive performance of ducks were shown in Table 2. Most of the farmers depended on natural feed $(60 \%)$ while some provided supplementary feed $(40 \%)$ to their ducks. Duckweed and snails $(56 \%)$ were prevailed in the study area as a natural feed ingredient compared to the separate use of them. Vaccination was not 
Table 2. Farm characteristics and productive performance of ducks as "good producer" and those laid $\leq 114$ eggs as "poor producer" by the researcher. Regular use of anthelmintics $(\mathrm{p}$ value $=0.001)$, treatment of

\begin{tabular}{|c|c|c|c|c|c|}
\hline \multirow[t]{2}{*}{ SL. NO. } & \multirow[b]{2}{*}{ Variables } & & \multicolumn{3}{|c|}{ Results } \\
\hline & & & Frequency & Percentage & Cumulative \% \\
\hline \multirow[t]{3}{*}{1.} & Types of feeding & Natural & 5 & 16.7 & 16.7 \\
\hline & & Additional & 6 & 20.0 & 36.7 \\
\hline & & Both & 19 & 63.3 & 100.0 \\
\hline \multirow[t]{3}{*}{3.} & Natural feed ingredient & Duck weed & 5 & 16.7 & 16.7 \\
\hline & & Snail & 8 & 26.7 & 43.3 \\
\hline & & $\begin{array}{l}\text { Combination of duck weed, } \\
\text { snail }\end{array}$ & 17 & 56.7 & 100.0 \\
\hline \multirow[t]{7}{*}{5.} & Additional feed ingredients & Rice polish & 8 & 26.7 & 26.7 \\
\hline & & Boil rice & 4 & 13.3 & 40.0 \\
\hline & & Paddy & 4 & 13.3 & 53.3 \\
\hline & & Broken rice & 4 & 13.3 & 66.7 \\
\hline & & Wheat bran & 2 & 6.7 & 73.3 \\
\hline & & Rice polish and boil rice & 5 & 16.7 & 90.0 \\
\hline & & Paddy and boil rice & 3 & 10.0 & 100.0 \\
\hline \multirow[t]{3}{*}{7.} & Type of vaccine used & Duck plague & 9 & 30.0 & 30.0 \\
\hline & & $\begin{array}{l}\text { Both duck plague and duck } \\
\text { cholera }\end{array}$ & 5 & 16.7 & 46.7 \\
\hline & & No vaccine & 16 & 53.3 & 100.0 \\
\hline \multirow[t]{3}{*}{9.} & Season when duck infected & Summer & 4 & 13.3 & 13.3 \\
\hline & & Monsoon & 7 & 23.3 & 36.7 \\
\hline & & Winter & 19 & 63.3 & 100.0 \\
\hline \multirow[t]{5}{*}{10.} & Egg production (Number) & Deshi white & & $90 \pm 2$ & \\
\hline & Per duck/year & Deshi black & & $105 \pm$ & \\
\hline & & Deshi mix & & $112 \pm$ & \\
\hline & & Zending & & $150 \pm 8.9$ & \\
\hline & Average (Number) & & & $114 \pm$ & \\
\hline 11. & $\begin{array}{l}\text { Mean age at first laying (in } \\
\text { months ) }\end{array}$ & & 5.85 & $.35(5-6.6)$ & \\
\hline
\end{tabular}

regular in the study area. The diseases were more common during winter $(63 \%)$ than other seasons of the year. Duck started their first laying at 6 months of age. The egg productions (number) per duck per year of different available breeds are shown in Table 2 . The highest deshi white produced lowest $(90 \pm 21.5 /$ duck/year) eggs than other available whereas Zending breed produced highest eggs

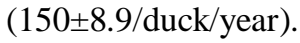

\section{Factors associated with productive performance of ducks}

The ducks were categorized as good egg producer and poor egg producer based on their egg production per year. The mean egg production per duck per year was 114 . Ducks those laid >114 eggs were assumed diseased duck $(\mathrm{p}=0.024)$, providing supplementary feed ingredients $(\mathrm{p}=0.004)$ and presence of marshy lands $(\mathrm{p}=0.009)$ were positively associated with higher egg production. Anthelmintics reduce the burden of parasites and thus the nutrients are more utilized for egg production ${ }^{[11]}$.

Presence of marshy lands was helpful for good egg production. Different types of faunas such as snails, fish, earthworms and flora such as duckweed and algae are grown in such marshy lands. All these feeds are rich sources of protein, minerals and vitamins that help meeting different types of nutrient requirements needed by ducks and increasing their productivity which was also reported by Khanum $(2005)^{[5]}$. 
Provision of supplementary feed enhances the nutritional status of the duck. The scavenging source of feed may not be balanced or not be adequate for duck nutrition. Supplementary feed helps ducks attain its maximum productivity. Treating the diseased ducks with antibiotics reduces the bacterial burden from gut and allows more utilization of feed ingredients ${ }^{[12]}$. These may allow additional nutrition and thereby better performance by the treated ducks were observed.

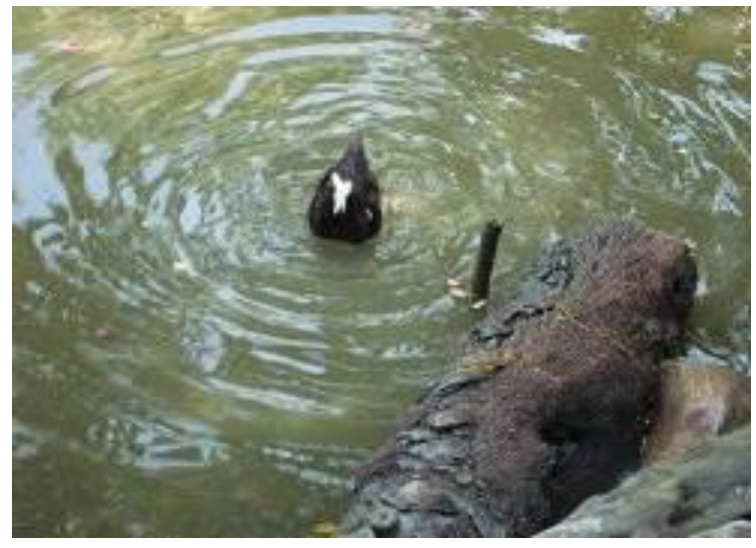

Figure 1. Natural feeding by duck (Grazing of duck)

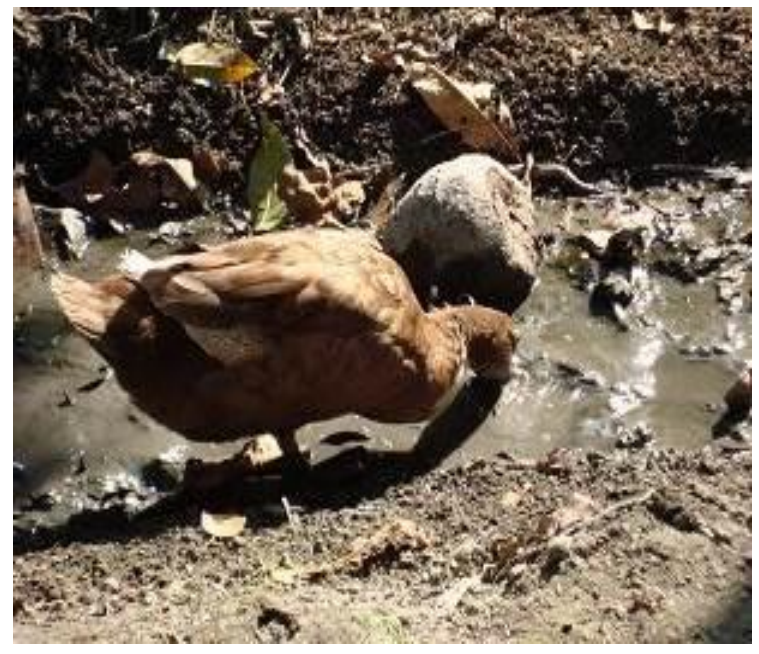

\section{Productive performances of different variety of ducks}

There were four varieties of ducks were found in the study area like deshi white, deshi black, deshi mix and Zending. Deshi mix were most prevailing ducks (33\%) followed by deshi black (23\%) Zending (30\%) and deshi white (14\%). The productive performance of different variety of ducks were evaluated and found that $85 \%$ Zending were good producer (Figure $2)$. Zending is well adapted in marshy land of Bangladesh and had shown better egg production performance ${ }^{[13]}$. Therefore, it can be recommend rearing Zending more abundantly in marshy area like Noakhali.

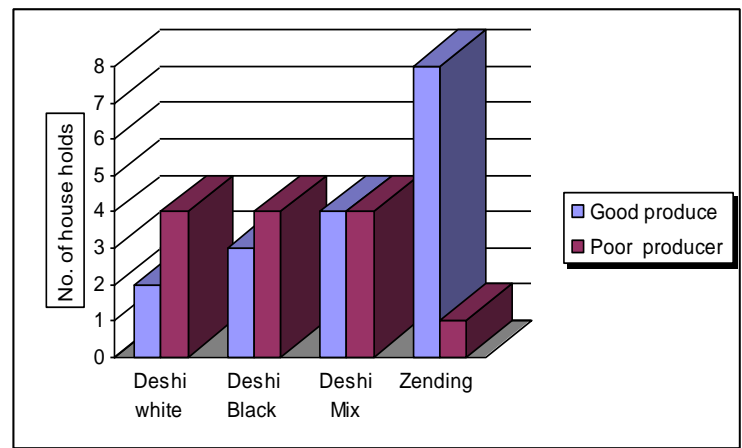

Figure 2. Egg production performance of different variety of ducks under study area

\section{CONCLUSION}

It reveals that the duck rearing are dominated by women and a good amount of marshy land is available in the studied area. Ducks are scavengers on the natural water sources. Duck rearing cost is lower than chicken rearing in this area and duck are treated good egg producers than local chickens. If proper management and vaccination can be followed then duck rearing will be more economic and sustainable in the coastal belt of Bangladesh.

\section{ACKNOWLEDGEMENT}

The authors are grateful to DR. Md. Abul Kalam, Veterinary Surgeon, Upazilla Livestock Office, Companiganj, Noakhali ,Bangladesh for his kind help and cooperation in during this study.

\section{REFERENCES}

1. Khan, M.K.I., Ali, A. \& Bhuiyan, A.K.F.H. 1999. Economic traits of Deshi males with Isa brown females under farm and rural conditions. Bangladesh J Anim. Sci., 28: 1-7.

2. Singh, R.A. 2001. Poultry Production, 3rd Edition, Kalyani Publishers, New DelhiLudhiana, India. 345 pp.

3. Saleque, M.A. and Mustafa, S. 1996. "Landless women and poultry: The BRAC Model in Bangladesh", in Frands Dolberg and Poul Henning Petersen (eds.), Integrated Farming in Human Development, Proceeding of the Workshop March 25-29, Tune Landboskole, Denmark, 38-55.

4. Huque, Q. M. E. and Hossain, M. J. 1991. Production potentiality of duck under scavenging system of management. Bangladesh J. Anim. Sci. 20(1 \&2): 119-122.

5. Khanum, J., Chwalibog, A. and Huque, K. S. 2005. Study on rural duck production systems in selected areas of Bangladesh. Livest. Res. Rural Devel. 17(10). 
6. Saleque, M.A. 1999. Scaling-up: Critical factors in leadership, management, human resource development and institution-building in going from pilot project to large-scale implementation: The BRAC poultry model in Bangladesh. In F. Dolberg \& P.H. Petersen, eds. Poultry as a Tool in Poverty Eradication and Promotion of Gender Equality, pp. 51-71. Proceedings workshop, March 22-26, 1999, Tune Landboskole, Denmark (http://www.husdyr.kvl.dk/htm/php/tune99/5Saleque.htm).

7. Huque, K. S. and N. Sultana 2002. Study on the existing duck production systems in Bangladesh. A report of Bangladesh Livestock Research Institute, Bangladesh.

8. Huque, Q. M. E., Ukil, M. A. and Hossain, M. J. 1993. Supplementary feeding of laying ducks, under scavenging condition. Bangladesh J. Livest. Res. 1: 57-62.

9. Maijer, A. M. 1987. Backyard poultry in the coastal area of rural Bangladesh Department of Tropical Animal Production, National Agricultural University, Wageningen, The Netherlands.

10. Steel, R.G.D., Torrie, J.H. and Dickey, D.A. 1997. Principles and procedures of statistics- $A$ biometrical approach. Mc Graw-Hill Co., Inc., New York and London. Pp: 139- 177

11. Farjana, T., Islam, K.R. and Mondal, M. M. H. 2008. Population Density of Helminthes in Ducks: Effects of host's age, sex, breed and season. Bangladesh J. Vet. Medic. 6 (1): 45-51.

12. Cook, M. E. 2004. Antibodies: Alternatives to Antibiotics in Improving Growth and Feed Efficiency. J. Appl. Poult. Res., 13:106-119.

13. Das, G. B. and Hoq, M.E. 2000. Performance of Khaki Campbell, Zending and khaki campbells indigenous ducks in integrated fishcum-duck farming system. Bangladesh J. Anim. Sci., 29(1-2): 111-117. 